\title{
New findings and a new species of the genus Ammothea (Pycnogonida, Ammotheidae), with an updated identification key to all Antarctic and sub-Antarctic species
}

\author{
E. Cano-Sánchez • P. J. López-González
}

Received: 4 September 2013/Revised: 28 November 2013/Accepted: 2 December 2013/Published online: 17 January 2014 (c) Springer-Verlag Berlin Heidelberg and AWI 2014

\begin{abstract}
Specimens of the pycnogonid genus Ammothea collected during the Polarstern cruise XXIII/8 (23 November 2006-30 January 2007) were studied. Nine species were recognized in this collection: Ammothea bentartica, A. bicorniculata, A. carolinensis, A. clausi, A. longispina, A. minor, A. spinosa, A. striata and A. tibialis. Three of them (A. bentartica, A. bicorniculata and A. tibialis) are reported for the second time, enlarging their known geographical and bathymetric range. In the present contribution, the observed morphological variability of all collected Ammothea species is described and discussed. For the identification and description of the material, different museum specimens were consulted. Among them, we have consulted part of the Discovery collection housed at the Natural History Museum in London. That material was initially identified by Isabella Gordon, a reputed author in the field of pycnogonid taxonomy. A new species, based on a museum specimen previously highly confused in the literature, is proposed in the present contribution as Ammothea isabellae $\mathrm{n}$. sp. The new taxon is compared with its closest congeners, especially with A. longispina and $A$. stylirostris. Finally, we propose an updated dichotomous key to species covering all currently known Antarctic and sub-Antarctic Ammothea species.
\end{abstract}

Communicated by H.-D. Franke.

E. Cano-Sánchez $(\bowtie)$ · P. J. López-González

Biodiversidad y Ecología de Invertebrados Marinos,

Departamento de Zoología, Facultad de Biología, Universidad de

Sevilla, Avda. Reina Mercedes 6, 41012 Seville, Spain

e-mail: ecano@us.es

P. J. López-González

e-mail: pjlopez@us.es
Keywords Antarctica - Subantarctica - Sea spider . Ammothea species · Key to species

\section{Introduction}

The Antarctic marine fauna has been intensively studied during recent decades, and it has been established that the Antarctic continental shelf shelters one of the richest benthic faunas in the oceans of the world (Arntz et al. 1994). Pycnogonids are an important component of this fauna and have intensively studied.

The pycnogonid family Ammotheidae is one of the best represented in Antarctic and sub-Antarctic waters, with Ammothea Leach 1814 being the best represented genus, currently including about 30 Antarctic and sub-Antarctic species among the 41 recognized species in the genus (Munilla and Soler-Membrives 2009; Cano and LópezGonzález 2013).

The most recent reports on the Ammotheidae from Antarctic and sub-Antarctic waters are those of Arnaud et al. (1986; King George Island and South Shetlands Islands), Bamber (2011; King George Island), Child (1994; various Antarctic areas), Chimenz Gusso and Gravina (2001; Magellanic Strait and Ross Sea), Fry and Hedgpeth (1969; Ross Sea), Munilla (2000, 2001, 2002; Scotia Sea, Drake Passage, Antarctic Peninsula and surrounding islands waters), Munilla and Soler-Membrives (2007; Bransfield Strait), Turpaeva (1974; Scotia Sea), Pushkin (1993; different Antarctic areas), Soler-Membrives et al. (2009; Eastern Weddel Sea), Nielsen et al. (2009; Ross Sea) and Cano and López-González (2007, 2013; Ross Sea and South Shetlands Islands). Among all these authors, Child's as well as Fry and Hedgpeth's contributions also summarized references and the 
historical background of previous investigations from this area.

Most Antarctic and sub-Antarctic Ammothea species are endemic to the Southern Ocean. However, the exact limits of distribution are often not clear, mainly because of a lack of information about character variability and the taxonomic value of these characters. Some artificial keys have been proposed to help with the initial identification of Ammothea species (Gordon 1932; Fry and Hedgpeth 1969; Clark 1977; Child 1994), but a continuous update of these tools is necessary, as well as the addition of information about the variability of some characters. These keys may often become unreliable when new information from new collections or redescriptions is available.

In this paper, data on Ammothea species collected in the course of the Polarstern cruise XXIII/8 (23 November 2006-30 January 2007) to the South Shetland and Joinville islands area are presented. Each Ammothea species is described, including (when necessary) illustrations. The variability observed in some characters when compared to previously published literature is briefly discussed. During this investigation, the examination of old collected specimens deposited in the Museum of Natural History in London led us to propose a new species based on a specimen previously identified at generic level by Gordon (1932). Finally, an updated key to Antarctic and sub-Antarctic species of Ammothea prepared for adult forms is also presented in order to help further investigations.

\section{Materials and methods}

The material studied in this paper was collected during the Polarstern cruise XXIII/8 (November 23, 2006-January 30, 2007) by bottom trawl and a small Agassiz trawl at the South Shetlands Islands, Bransfield Strait and Joinville Island, Antarctica. Individuals were fixed in $10 \%$ buffered formalin and then transferred to $70 \%$ ethanol.

For comparative purposes, the type material of Ammothea longispina Gordon, 1932 deposited in the Natural History Museum has also been consulted (BMNH 1933.3.23.659), as well as a specimen initially identified as “Ammothea sp.?" (BMNH 1933.3.23.666), but considered by Fry and Hedgpeth (1969) and subsequent authors as the former species.

The specimens here examined have been deposited at the Museo de Zoología de Barcelona, Spain (MZB), and at the collection of the research group Biodiversidad y Ecología de Invertebrados Marinos (BEIM) at the University of Seville, Spain.

\section{Results}

Family Ammotheidae Dohrn, 1881

Genus Ammothea Leach, 1814

Ammothea bentartica Munilla, 2001

Ammothea bentartica Munilla, 2001, pp. 145-148, figs. 1-2.- Munilla and Soler-Membrives, 2009, p. 100 (list)

Material examined

MZB (2013-3690) one adult female, Polarstern cruise XXIII/8, stn. 605-1. Elephant Island, $61^{\circ} 20.35^{\prime} \mathrm{S}$ $55^{\circ} 29.16^{\prime} \mathrm{W}, 146-151 \mathrm{~m}$, Bottom trawl, 19 December 2006. BEIM (CRP-86) two adult females, Polarstern cruise XXIII/8, stn. 678-1, South Shetland Islands, $62^{\circ} 19.36^{\prime} \mathrm{S}$ $60^{\circ} 27.10^{\prime} \mathrm{W}, 109-129 \mathrm{~m}$, Bottom trawl, 2 January 2007. MZB (2013-3691) one adult females, Polarstern cruise XXIII/8, stn. 674-1, South Shetland Islands, $61^{\circ} 59.10^{\prime} \mathrm{S}$ 59 $55.57^{\prime} \mathrm{W}, 286-318$ m, Bottom trawl, 1 January 2007.

Diagnosis

Proboscis longer than the trunk, moderately slender, almost cylindrical with a feeble constriction at mid-length. Trunk with tall conical tubercles at dorsomedial points on segmentation ridges, shorter than ocular tubercle. Abdomen straight upward. Chelifores with no functional chelae. Palp 9-articled, second and fourth articles subequal in length; articles 5, 6 and 7 broader than long. Oviger strigilis with denticulate spines. Legs glabrous; tibia II is the longest article. Propodus with 8-9 spines along the entire sole. Auxiliary claws about half main claw length.

Geographical and bathymetric distribution

This species has only been reported in the original description by Munilla (2001) (one male, holotype and one male and one female, paratypes). The type locality is Livingston Island (South Shetland Islands, Antarctica), between 167 and 325 metres depth. Our specimens were collected off South Shetland Islands, between 109 and 318 metres depth. According to the above listed records, with our specimens, 7 individuals of this uncommon species are now known.

\section{Remarks}

The material examined for this study agrees in general aspects with the descriptions given by Munilla (2001). This author pointed out that this species is the first Antarctic one with denticulate spines on the strigilis, which can also be observed in our specimens. 


\section{Ammothea bicorniculata Stiboy-Risch, 1992}

Ammothea bicorniculata Stiboy-Risch, 1992

part Ammothea allopodes Munilla and Soler-Membrives, 2009, p. 100 (list.)

Material examined

MZB (2013-3692), one adult female, Polarstern cruise XXIII/ 8 , stn. 654-6, Elephant Island, $61^{\circ} 22.80^{\prime} \mathrm{S} 56^{\circ} 03.84^{\prime} \mathrm{W}$, 340-342 m, Agassiz trawl, 29 December 2006. BEIM (CRP87), one adult male, Polarstern cruise XXIII/8, stn. 616-1, Elephant Island, $60^{\circ} 49.81^{\prime} \mathrm{S} 55^{\circ} 36.76^{\prime} \mathrm{W}, 487-484 \mathrm{~m}$, Bottom trawl, 22 December 2006. MZB (2013-1873), one larvigerous male, Polarstern cruise XXIII/8, stn. 687-1, Joinville Island, $62^{\circ} 35.19^{\prime} \mathrm{S} 54^{\circ} 45.99^{\prime} \mathrm{W} 263-257 \mathrm{~m}$, Bottom trawl, 4 January 2007.

\section{Diagnosis}

Proboscis shorter than trunk, rounded with a proximal constriction, less than twice as long as wide. Three anterior trunk segments with tall dorsomedial tubercles. Ocular tubercle as tall as dorsomedial tubercles. Anterior cephalic segment with tubercles, dorsal to chelifore insertion. Abdomen nearly horizontal or slightly upward, with low spinulose basal tubercle. Chelifores with functional chelae, scape longer than half proboscis length. Palp 9-articled, second and fourth articles subequal in length. Legs with four longitudinal bands of spinules, tibia II is the longest article. Propodus with two heel spines. Auxiliary claws about half main claw length.

Geographical and bathymetric distribution

This species has only been reported in the original description by Stiboy-Risch (1992) (one female, holotype and one male, paratype). Holotype locality is Princess Martha Coast (Weddell Sea) (473 m depth), and paratype locality is Elephant Island (220 m depth). Our specimens were collected off Elephant Island and Joinville Island, between 257 and $486 \mathrm{~m}$ depth. According to the above listed records, with our specimens, 5 individuals of this uncommon species are now known.

\section{Remarks}

The material examined for this study agrees in general aspects with the descriptions given by Stiboy-Risch (1992). However, the holotype original figure shows dorsomedial tubercles steep-sided and slightly rounded or flat topped. Our specimens show tall and pointed dorsomedial tubercles, also the size of body and the spination of legs is variable; one male shows spination similar to the holotype, and the other male and the female show reduced spinules.

Munilla (2001) succinctly mentioned that Ammothea bicorniculata is probably a junior synonym of A. allopodes, but without further indications. Some years later on, $\mathrm{Mu}$ nilla and Soler-Membrives (2009) considered (in their species list) this synonym, but it was not discussed. However, characters such as the presence of functional chelifores and a similar propodus in all four legs could be considered useful for separating A. bicorniculata from $A$. allopodes.

Ammothea carolinensis Leach, 1814

Ammothea carolinensis Leach, 1814, p. 34, pl. XIII.Calman, 1920, pp. 246-247.- Clark, 1977, pp. 174-175 (key).- Munilla, 1991, pp. 22-23.- Müller, 1993, pp. 27-28.Child, 1994, pp. 18-19.- Chimenz Gusso and Gravina, 2001, p. 338.- Munilla, 2001, p. 145 (list.).- Munilla and SolerMembrives, 2009, p. 100 (list.).- Nielsen et al., 2009, p. 1150 (list.).- Bamber, 2011, p. 30.

Ammothea grandis Pfeffer, 1899, p. 43.- Bouvier, 1913, p. 126.- Hodgson, 1927, p. 341.

Ammothea curculio Bouvier, 1906a, p. 20.- Bouvier, 1906b, p. 40.- Hodgson, 1927, p. 341.

Leionymphon grande. Bouvier, 1906b, pp. 60-5, pl. III.Hodgson, 1907, pp. 41-3, pl. VI.- Hodgson, 1908, 169-170.- Bouvier, 1911, 1140.

Leionymphon gibbosum. Hodgson, 1907, p. 40 (list.).

Ammothea gibbosa. Bouvier, 1913, p. 127, figs. 78-82.Calman, 1915, pp. 51-52.- Gordon, 1938, pp. 20-21.Gordon, 1944, p. 52.- Hedgpeth, 1950, p. 152.

Ammothea (Ammothea) carolinensis. Fry and Hedgpeth, 1969, pp. 73-75, figs. 104-108.- Turpaeva, 1974, p. 284.Turpaeva, 1998, p. 57.- Pushkin, 1993, pp. 286-288, fig. 252.

Colossendeis gibbosa Möbius, 1902, pp. 192-193, pl. XXX.

Colossendeis ? charcoti Bouvier, 1905, p. 296.

Material examined

MZB (2013-3693); MZB (2013-1867), one adult female and one larvigerous male, Polarstern cruise XXIII/8, stn. 614-3, Elephant Island, $60^{\circ} 52.37^{\prime} \mathrm{S} 55^{\circ} 29.80^{\prime} \mathrm{W}, 248-259 \mathrm{~m}$, Agassiz trawl, 21 December 2006. BEIM (CRP-88); MZB (20133694); MZB (2013-1869); MZB (2013-1870); BEIM (CRP83), three adult females and three larvigerous male, Polarstern cruise XXIII/8, stn. 605-1. Elephant Island, $61^{\circ} 20.35^{\prime} \mathrm{S}$ 55 29.16'W, 146-151 m, Bottom trawl, 19 December 2006. MZB (2013-3695), one adult female, Polarstern cruise XXIII/ 8 , stn. 657-1, Elephant Island, $61^{\circ} 14.28^{\prime} \mathrm{S} 55^{\circ} 48.96^{\prime} \mathrm{W}$, 133-145 m, Bottom trawl, 29 December 2006. MZB 
(2013-3696), one adult female, one adult male and one ovigerous male, Polarstern cruise XXIII/8, stn. 668-1, South Shetland Islands, $61^{\circ} 49.32^{\prime} \mathrm{S} 58^{\circ} 34.74^{\prime} \mathrm{W}, 193-152 \mathrm{~m}$, Bottom trawl, 31 December 2006. MZB (2013-3697), one adult female, Polarstern cruise XXIII/8, stn. 700-2, Larsen B, corestation South, $65^{\circ} 55.07^{\prime} \mathrm{S} 60^{\circ} 20.15^{\prime} \mathrm{W}, 445-442 \mathrm{~m}$, Bottom trawl, 11 January 2007. MZB (2013-3698), one adult female, Polarstern cruise XXIII/8, stn. 670-1, South Shetland Islands, $61^{\circ} 51.69^{\prime} \mathrm{S} 59^{\circ} 15.43^{\prime} \mathrm{W}, 263-270 \mathrm{~m}$, Bottom trawl, 1 January 2007. MZB (2013-3699), one ovigerous male, Polarstern cruise XXIII/8, stn. 608-1, Elephant Island, $61^{\circ} 11.34^{\prime} \mathrm{S} 54^{\circ} 43.17^{\prime} \mathrm{W}$, 293-284 m, Bottom trawl, 20 December 2006. BEIM (CRP82), one larvigerous male, Polarstern cruise XXIII/8, stn. 614-1, Elephant Island, $60^{\circ} 52.52^{\prime} \mathrm{S} 55^{\circ} 29.21^{\prime} \mathrm{W}, 250-245 \mathrm{~m}$, Bottom trawl, 21 December 2006. MZB (2013-1868), one larvigerous male, Polarstern cruise XXIII/8, stn. 640-1, Elephant Island, $61^{\circ} 12.72^{\prime} \mathrm{S} 55^{\circ} 52.29^{\prime} \mathrm{W}, 136-154 \mathrm{~m}$, Bottom trawl, 26 December 2006. MZB (2013-1866), one larvigerous male, Polarstern cruise XXIII/8, stn. 605-1, Elephant Island, $61^{\circ} 20.35^{\prime} \mathrm{S} 55^{\circ} 29.16^{\prime} \mathrm{W}, 151-146 \mathrm{~m}$, Bottom trawl, 19 December 2006.

\section{Diagnosis}

Proboscis longer than trunk, swollen towards mid-length. Three anterior trunk segments with broad dorsomedial tubercles. Ocular tubercle shorter than dorsomedial tubercles. Chelifores very short, no functional chelae, downcurved. Palp 9-articled, fourth article the longest palp article and the terminal 4 articles tubular in shape. Legs slender, second tibiae the longest of major articles, spination variable. Propodus with 3 heel and in most cases one sole spine. Auxiliary claws about half main claw length.

Geographical and bathymetric distribution

Fry and Hedgpeth (1969) and Child (1994) summarized the geographical and bathymetric information concerning this species. According to these authors, A. carolinensis should be considered circumpolar, living between 10 and $640 \mathrm{~m}$; the bathymetric range was slightly increased in Munilla (2001) and Munilla and Soler-Membrives (2009) 3-670 m. Our sampling data do not modify the known geographical and bathymetric distribution of this species.

\section{Remarks}

This is the most common Antarctic Ammothea species. Several species have been synonymised with A. carolinensis over the years, but its characters are considered to be sufficiently homogeneous to remain a single species (Child 1994). Fry and Hedgpeth (1969) pointed to the spination of the walking leg as the only possible character that could be objectively compared for delimiting new species within $A$. carolinensis variability. However, after the examination of their available materials, they considered leg spination may be influenced by very local environmental conditions or that this species is polymorphic with respect to this character.

The material examined for this study agrees in general aspects with the diagnosed set of characters given by Fry and Hedgpeth (1969), Munilla (1991), Child (1994) and Chimenz and Gravina (2001), although there are some differences in propodus spination between the various published descriptions. Fry and Hedgpeth (1969) described the spination of the propodus as variable between three and four heel spines (equal or slightly varying in size), and in most specimens, there was an additional sole spine, while Child (1994) described the propodus spination as "1 major heel spine and 2 smaller spines distal to it". Our specimens show propodus spination coincident with Fry and Hedgpeth's (1969) and Munilla's (1991) description: three heel spines, although the relative sizes of these spines are similar to those observed by Munilla (1991, fig. 8b), proximal spine slightly shorter than the two subsequent ones, and one shorter sole distal spine.

\section{Ammothea clausi Pfeffer, 1889}

Ammothea clausi Pfeffer, 1889, p. 45. Bouvier, 1913, pp. 135-138, 88-89. Hodgson, 1927, p. 342, 343 (key). Gordon, 1932, pp. 109-110. Hedgpeth, 1950, p. 152. Clark, 1977, pp. 174-175 (key). Pushkin, 1993, pp. 290-291, fig. 256. Child, 1994, pp 19-20. Chimenz Gusso and Gravina, 2001, p. 338.Munilla, 2000, p. 49 (list.). Munilla, 2000, p. 49 (list.). Munilla, 2001, p. 145 (list). Munilla and SolerMembrives, 2009, p. 100 (list.). Bamber, 2011, p. 30.

Ammothea antarctica Bouvier, 1905, p. 296. Bouvier, 1906a, p. 19.

Leionymphon antarcticum. Bouvier, 1906b, pp. 56-60, 37-39, pl. III.

Leionymphon clausi. Hodgson, 1907, p. 40 (list). Hodgson, 1908, pp. 160-71, pl. II. Bouvier, 1911b, 1140. Helfer and Schlottke, 1935, p. 284.

Leionymphon australe Hodgson, 1907, p- 46-49, pl. VII (fig. 1).

Ammothea australis. Bouvier, 1913, p. 123 (key). Calman, 1915, p. 53. Hodgson, 1927, p. 341, p. 342 (key). Gordon, 1938 , p. 20.

Ammothea australe. Loman, 1923, p. 23.

Ammothea (Theammoa) clausi. Fry and Hedgpeth, 1969, pp 77-79, figs. 112-115.

Material examined

MZB (2013-3700), one adult female, Polarstern cruise XXIII/8, stn. 613-1, Elephant Island, $60^{\circ} 55.99^{\prime} \mathrm{S}$ 
$55^{\circ} 28.53^{\prime} \mathrm{W}, 113-157 \mathrm{~m}$ depth, Bottom trawl, 21 December 2006. MZB (2013-3701), three adult females, Polarstern cruise XXIII/8, stn. 668-1, South Shetland Islands, $61^{\circ} 49.32^{\prime} \mathrm{S} 58^{\circ} 34.74^{\prime} \mathrm{W}, 193-152 \mathrm{~m}$, Bottom trawl, 31 December 2006. BEIM (CRP-90), one adult male, Polarstern cruise XXIII/8, stn. 614-3, Elephant Island, $60^{\circ} 52.37^{\prime} \mathrm{S} 55^{\circ} 29.80^{\prime} \mathrm{W}, 248-259 \mathrm{~m}$, Agassiz trawl, 21 December 2006. MZB (2013-3702), four adult females, Polarstern cruise XXIII/8, stn. 679-1, South Shetland Islands, $62^{\circ} 23.84^{\prime} \mathrm{S} 60^{\circ} 48.79^{\prime} \mathrm{W}, 87-91 \mathrm{~m}$, Bottom trawl, 2 January 2007. MZB (2013-3703), one adult male, Polarstern cruise XXIII/8, stn. 616-1, Elephant Island, $60^{\circ} 49.81^{\prime} \mathrm{S} 55^{\circ} 36.76^{\prime} \mathrm{W}, 487-484 \mathrm{~m}$, Bottom trawl, 22 December 2006. BEIM (CRP-89), five adult females, Polarstern cruise XXIII/8, stn. 679-1, South Shetland Islands, $62^{\circ} 23.84^{\prime} \mathrm{S} 60^{\circ} 48.79^{\prime} \mathrm{W}, 87-91 \mathrm{~m}$, Bottom trawl, 2 January 2007. MZB (2013-1871); BEIM (CRP-84), two larvigerous males, Polarstern cruise XXIII/8, stn. 674-1, South Shetland Islands, $61^{\circ} 59.10^{\prime} \mathrm{S} 59^{\circ} 55.57^{\prime} \mathrm{W}, 286-318 \mathrm{~m}$, Bottom trawl, 1 January 2007.

\section{Diagnosis}

Proboscis pyriform shape. Trunk with transverse body ridges low without medial tubercles. Ocular tubercle conical and pointed. Lateral processes with paired dorsodistal tubercles. Chelifores slender, chelae atrophied. Palp 9-articled, second article the longest palp article. Legs with four longitudinal bands of spinules, tibia II is the longest article. Propodus sole spination varies between 2 and 8 spines, the most proximal spine markedly smaller.

Geographical and bathymetric distribution

Fry and Hedgpeth (1969), Pushkin (1993) and Child (1994) summarized the geographical and bathymetric information concerning this species. According to these authors, this species should be considered circumpolar, living between 3 and 860 metres. The newly collected specimens do not modify the known distribution or depth range of $A$. clausi.

\section{Remarks}

Fry and Hedgpeth (1969) considered Ammothea clausi as a dimorphic species, possibly heading towards a speciation event. They discussed two geographical forms, the "Magellanic form" and the "Victoria Land form", the vertical posture of the abdomen and the steep, sharp, ocular tubercle being the character states. In fact, the "Victoria Land form" had been called A. australis (Hodgson 1907) for many years until Fry and Hedgpeth synonymised the two species because they found specimens intermediate in their critical characters.
Our specimens are similar to "Magellanic form", except one male (CRP-90) with intermediate critical characters, it has an abdomen like "Magellanic form" and ocular tubercle similar to "Victoria Land form" (but flattened with two little cones). If this is an example of a very variable species or whether it should be considered, a complex of different species is a question which must be dealt with in a different contribution, including biometry on a large number of specimens and probably molecular information.

Ammothea isabellae n. sp. (Figs 1, 2)

Ammothea sp.? Gordon, 1932, pp. 108-109, fig. 58. part Ammothea (Homathea) longispina. Fry and Hedgpeth, 1969, pp. 88-90, figs. 132-136.

part Ammothea longispina. Child, 1994, p. 24.

Material examined

BMNH (1933.3.23.666) one female, holotype, Discovery Expedition, Stn. W S 216, 1 June $1928.47^{\circ} 37^{\prime} \mathrm{S} 60^{\circ} 50^{\prime} \mathrm{W}$, 219-133 m., f. S. Commercial otter trawl, 1925-31.

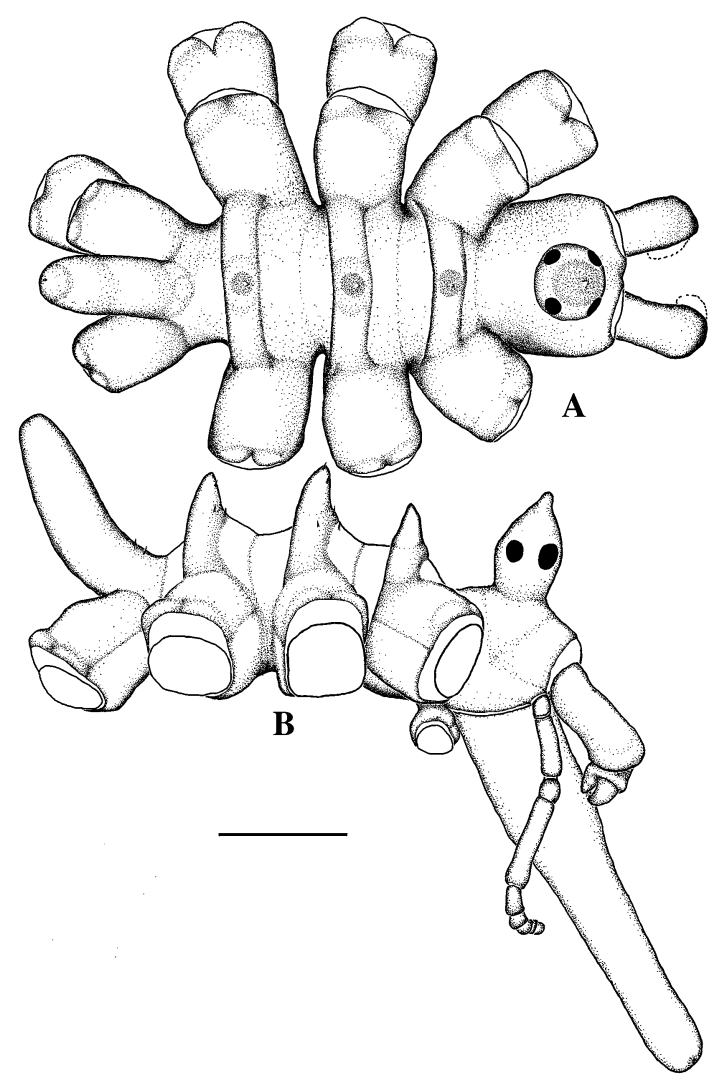

Fig. 1 Ammothea isabellae sp. nov. Holotype, female. a Dorsal view; b lateral view (showing the relative size and distribution of spinules). Scale $2 \mathrm{~mm}$ 
Fig. 2 Ammothea isabellae sp. nov. Holotype, female. a Third leg, right (scale $5 \mathrm{~mm}$ ); b Chelifore (scale $0.5 \mathrm{~mm}$ ); c Distal third leg articles (scale $1 \mathrm{~mm})$; d detail from $\mathrm{c}$; e Oviger (scale $1 \mathrm{~mm}$ ); f. Left palp.; g Right palp (drawn by Gordon, 1932) (scale f and g $1.5 \mathrm{~mm}$ )

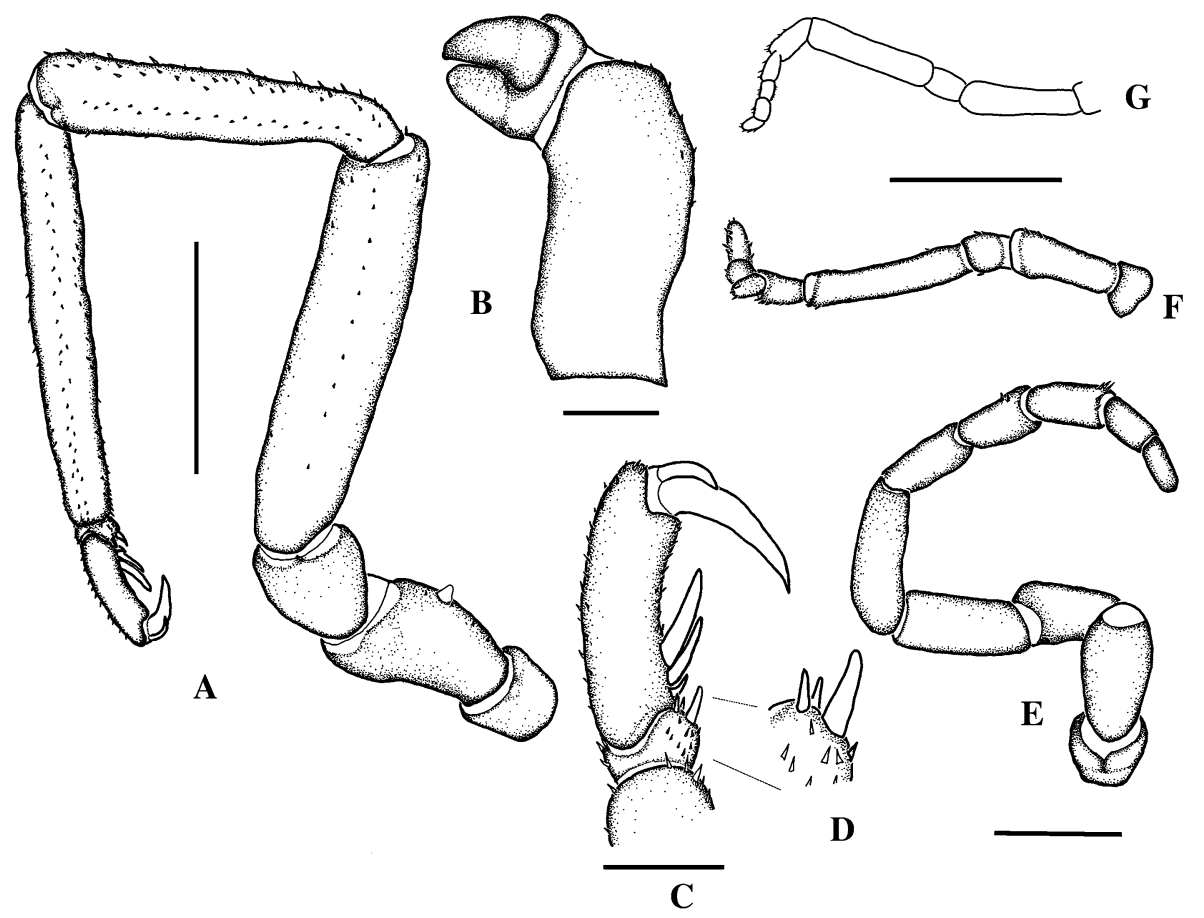

\section{Description of the holotype (female)}

Size moderately small, leg span $73 \mathrm{~mm}$. Proboscis styliform, straight, slender; widest in proximal half length. Proboscis shorter than trunk length. Trunk broad, oval, and fully segmented, with lateral processes separated, less than half of process diameter. Lateral processes with two low dorsodistal tubercles. Cephalic segment without dorsofrontal tubercles. Conical dorsal processes on the three anterior trunk segments. Trunk segments with scattered short spines. Abdomen long and erect. Ocular tubercle with a slightly rhomboidal profile in lateral view, taller than wide, topped by a cone, and taller than dorsomedial tubercles. Four eyes, anterior pair slightly larger than posterior pair.

Chelifores not functional, chelae with reduced fingers. Scape one-articled, slightly down curved, less than half of proboscis length. Chelae antero-ventrally oriented.

Palps 9-articled, slender, spinulose, shorter than proboscis. Second article shorter than fourth; without strong ectal mound surmounted by a pore.

Oviger ten-articled. Eighth article articulated syntaxially with seventh. Articles without or with scarce spinules, these are distally placed in articles 7-10, but more disperse in articles 5 and 6.

Legs slender. First coxa with two dorsolateral tubercles similar to those on lateral processes; the second coxa is the longest and has a dorsomedial pore on top of protuberance. Second tibia and femur are subequal and are the longest articles. Articles with scattered spines mainly forming six bands (two dorsal, two lateral and two ventral), and these bands are not clearly defined on tarsus and propodus. Oval sexual pores located ventrally on the second coxa in all legs. Tarsus short, with three ventrodistal spines. Propodus similar in all legs, with three heel spines increasing in size distally and covering less than the proximal half of the propodus. Main claw longer than 0.5 times length of propodus; auxiliary claws about 0.36 times length of main claw.

\section{Measurements of holotype (mm)}

Length of trunk (tip of the cephalic segment to the tip of fourth lateral processes): 7.7. Width of trunk across second lateral processes: 5.9. Length of proboscis: 6.8. Basal diameter of proboscis: 1.5. Greatest diameter of proboscis: 1.5. Length of abdomen: 2.7. Length of chelifore: 2.4. Length of scape: 1.7. Length of chelae and palm: 0.7. Length of palp (right palp after Gordon's image): 4.1; length of palp articles (first to ninth): $0.3,1,0.3,1.2,0.4$, $0.3,0.2,0.2,0.2$. Length of third leg: 33.5 ; length of articles of leg 3: coxa 11.5 , coxa 23 , coxa 32 , femur 8.5, tibia 17 , tibia 29 , tarsus 0.5 , propodus 2.4 , claw 1.4 , auxiliary claws 0.5 . Length of oviger: 5.2 ; length of oviger articles (first to 10th): $0.4,1.1,0.7,1.1,1.2,0.8,0.6,0.7,0.5,0.5$.

Etymology

This species is named in homage to Isabella Gordon, for her important contribution to our knowledge of the 
pycnogonid fauna of the Southern Ocean, and for being the first author who examined the material presently proposed as a new species.

Geographical and bathymetric distribution

At present, Ammothea isabellae n. sp. is only known from its type locality in the south-eastern Atlantic $\left(47^{\circ} 37^{\prime} \mathrm{S}\right.$ $\left.60^{\circ} 50^{\prime} \mathrm{W}\right), 219-133 \mathrm{~m}$ depth.

\section{Remarks}

Initially, the material here considered as Ammothea isabellae n. sp. was described as Ammothea sp. by Gordon (1932) because it bears a strong superficial resemblance to the holotype of Ammothea longispina. Later Fry and Hedgpeth (1969), Child (1994) and Pushkin (1993) considered both materials as belonging to the same species, as A. longispina. Fry and Hedgpeth (1969) consulted Gordon's material and apparently drew the specimen of Ammothea sp. as the general figure of A. longispina (see Fry and Hedgpeth 1969, fig. 133 and fig. 1 in this paper) as well as the terminal article of leg three (see Gordon 1932, fig. 58c and Fry and Hedgpeth 1969, fig. 134A), while other details illustrated on the palp and ovigerous were reproduced from Gordon's figures of A. longispina (see Gordon 1932, fig. 52a, b and Fry and Hedgpeth 1969, fig. 134C, B).

Ammothea isabellae $\mathrm{n}$. sp. is only comparable with $A$. longispina Gordon, 1932 and A. stylirostris Gordon, 1932 as they share the following set of characters: (1) adult chelifores with atrophied finger; (2) styliform proboscis; (3) transverse body ridges prominent, with conical dorsal processes; (4) second tibiae is the longest article; (5) propodus of all legs similar in proportion and sole armature.

A styliform proboscis is only present in three Ammothea species in the Southern Ocean: A. stylirostris, A. longispina and A. isabellae n. sp. (see Gordon 1932; Fry and Hedgpeth 1969; Pushkin 1993; Child 1994 and this paper). However, the proportions and shape of the proximal portions of the proboscis in the three species are distinctly different. In $A$. longispina, the proboscis is 6.5 times as long as wide, and the proximal part is narrower than the wider part, which is located in the first basal third. In A. stylirostris, the proboscis is 2.9 times as long as wide, and the proximal part is funnel shaped, with the wider part of the proboscis at the proximal border in contact with the cephalic segment. Finally, in A. isabellae n. sp., the corresponding proboscis length/width ratio is 4.5 , and the proximal part is cylindrical along the basal third of its length, this also being the widest part.

Ammothea isabellae n. sp. and A. stylirostris have a 9-articled palp, while in A. longispina, it is 8-articled. The combined length of the four first palp articles in Ammothea isabellae $\mathrm{n}$. sp. and A. longispina is shorter than half the proboscis length; while in A. stylirostris, it is nearer to the entire proboscis length (see fig. 1 in this paper, Gordon 1932, figs. 52 and 56).

Gordon (1932, in key, p. 95) pointed out for her specimens of "Ammothea sp.?", that the palp "is not quite normal and may be longer or at least equal to proboscis length", because she considered that "the terminal article of the right palp may have been regenerated" and that the left palp was undergoing regeneration. During the examination of the holotype, it can be seen that the right palp described and illustrated in detail by Gordon (1932, p.108) is lacking. Gordon also describes the regeneration state of the left palp (still present on the holotype and illustrated in this paper). In this case, for the above provided biometric data of the palp, we have only included that information extrapolated from Gordon's image with the dimension of the second article observed in the currently only existing palp in the designated holotype. However, it should be observed that there are slight differences in the proportions of palp articles two and four between the Gordon's image (right palp apparently in correct shape, see fig. 2G in this paper) and our image (left palp, assumed to be in regeneration, or to be considered theratologic, see fig. $2 \mathrm{~F}$ in this paper). For these reasons, the characters related to the relative proportions of palp articles are not used in this species comparison.

The ratio of the trunk length to proboscis length in the three species in this discussion is another distinguishing character. In Ammothea stylirostris, the trunk is longer than the proboscis (1.4 times based on the original holotype description), in A isabellae n. sp. is slightly longer (1.1 times based on the original description data and further holotype examination), while in A. longispina, the trunk is slightly shorter than the proboscis $(0.87$ times based on the holotype and 0.86 times based on six additional specimens).

Ammothea longispina possess blunt rounded tubercles on the anterior cephalic segment, in A. stylirostris these are low rounded tubercles, but $A$. isabellae n. sp. lacks tubercles on the anterior cephalic segment.

In reference to the propodal armature, Ammothea longispina has propodi with two heel spines of different sizes, while $A$. isabellae n. sp. has three heel spines (the proximal one shorter), and A. stylirostris has two heel spines and one medial spine of similar size.

In short, the diagnostic characters of A. isabellae n. sp. are: non-functional chelifores, proboscis cylindrical on its basal portion, proboscis slightly shorter than trunk, without tubercles on anterior cephalic segment, palp 9-articled shorter than proboscis and propodi with three heel spines. Table 1 summarizes the main differences between the species here compared. 
Table 1 Main differences between A. stylirostris, A. longispina and A. isabellae $\mathrm{n} . \mathrm{sp}$

\begin{tabular}{|c|c|c|c|}
\hline & A. stylirostris & A. longispina & A. isabellae $\mathrm{n} . \mathrm{sp}$ \\
\hline $\begin{array}{l}\text { Proboscis } \\
\text { shape }\end{array}$ & $\begin{array}{l}\text { Proximal part } \\
\text { funnel shaped, } \\
\text { wider part at } \\
\text { the proximal } \\
\text { border in } \\
\text { contact with the } \\
\text { cephalic } \\
\text { segment }\end{array}$ & $\begin{array}{l}\text { Proximal part } \\
\text { narrow, } \\
\text { wider part at } \\
\text { the first } \\
\text { basal third. }\end{array}$ & $\begin{array}{l}\text { Proximal part } \\
\text { cylindrical } \\
\text { along the basal } \\
\text { third of its } \\
\text { length, this also } \\
\text { being the } \\
\text { widest part. }\end{array}$ \\
\hline $\begin{array}{l}\text { Ratio } \\
\text { proboscis } \\
\text { length/ } \\
\text { width }\end{array}$ & 2.9 & 6.5 & 4.5 \\
\hline Palp articles & 9 & 8 & 9 \\
\hline $\begin{array}{l}\text { Combined } \\
\text { length of } \\
\text { the four } \\
\text { first palp } \\
\text { articles }\end{array}$ & $\begin{array}{l}\text { Nearer to the } \\
\text { entire proboscis } \\
\text { length }\end{array}$ & $\begin{array}{l}\text { Shorter than } \\
\text { half the } \\
\text { proboscis } \\
\text { length }\end{array}$ & $\begin{array}{l}\text { Shorter than half } \\
\text { the proboscis } \\
\text { length }\end{array}$ \\
\hline $\begin{array}{l}\text { Ratio trunk } \\
\text { length/ } \\
\text { proboscis } \\
\text { length }\end{array}$ & $\begin{array}{l}\text { Trunk longer } \\
\text { than proboscis }\end{array}$ & $\begin{array}{l}\text { Trunk slightly } \\
\text { longer than } \\
\text { proboscis }\end{array}$ & $\begin{array}{l}\text { Trunk slightly } \\
\text { shorter than } \\
\text { proboscis }\end{array}$ \\
\hline $\begin{array}{l}\text { Tubercles } \\
\text { on the } \\
\text { anterior } \\
\text { cephalic } \\
\text { segment }\end{array}$ & $\begin{array}{l}\text { Low rounded } \\
\text { tubercles }\end{array}$ & $\begin{array}{l}\text { Blunt rounded } \\
\text { tubercles }\end{array}$ & $\begin{array}{l}\text { Without } \\
\text { tubercles }\end{array}$ \\
\hline $\begin{array}{l}\text { Propodal } \\
\text { armature }\end{array}$ & $\begin{array}{l}\text { Two heel spines } \\
\text { and one medial } \\
\text { spine of similar } \\
\text { size }\end{array}$ & $\begin{array}{l}\text { Two heel } \\
\text { spines of } \\
\text { different } \\
\text { sizes }\end{array}$ & $\begin{array}{l}\text { Three heel spines } \\
\text { (the proximal } \\
\text { one shorter) }\end{array}$ \\
\hline
\end{tabular}

Ammothea longispina Gordon, 1932

Ammothea longispina Gordon, 1932, pp. 101-103, figs. 50-52.- Helfer and Schlottke, 1935, p. 235.-Gordon, 1944, pp. 49-50, fig. 16f.- Clark, 1977, p.174 (list), 175 (key).- Child, 1982, p.3.- Pushkin, 1993, pp. 297-298. - Munilla and Soler-Membrives, 2009, p. 100 (list.).- Nielsen et al., 2009, p. 1150 (list.).- Soler-Membrives et al., 2009, p. 1392 (list.).- Weis et al., 2011, p. 302.

Ammothea sp? Gordon, 1932, 108, fig. 58

part Ammothea (Homathea) longispina. Fry and Hedgpeth, 1969, pp. 88-90, figs. 132-136.

Ammothea (Homathea) longispina. Turpaeva, 1974, p. 284.

part Ammothea longispina. Child, 1994, p. 24.

Material examined

MZB (2013-3704), one adult female, Polarstern cruise XXIII/8, stn. 669-1, South Shetland Islands, 61 ${ }^{\circ} 49.97^{\prime} \mathrm{S}$ $58^{\circ} 41.30^{\prime} \mathrm{W}$, 208-192 m, Bottom trawl, 31 December
2006. BEIM (CRP-91), one adult female, Polarstern cruise XXIII/8, stn. 608-1, Elephant Island, $61^{\circ} 11.34^{\prime} \mathrm{S}$ $54^{\circ} 43.17^{\prime} \mathrm{W}, 293-284 \mathrm{~m}$, Bottom trawl, 20 December 2006. MZB (2013-1875); MZB (2013-3705), one larvigerous male and one adult female, Polarstern cruise XXIII/ 8 , stn. 661-2, South Shetland Islands, $61^{\circ} 39.29^{\prime} \mathrm{S}$ $57^{\circ} 02.89^{\prime} \mathrm{W}, 467-466 \mathrm{~m}$, Bottom trawl, 30 December 2006. MZB (2013-3706), one adult female, Polarstern cruise XXIII/8, stn. $629-1$, Elephant Island, $61^{\circ} 00.39^{\prime} \mathrm{S}$ $55^{\circ} 46.30^{\prime} \mathrm{W}, 162-191 \mathrm{~m}$, Bottom trawl, 24 December 2006. MZB (2013-1874), one larvigerous male, Polarstern cruise XXIII/8, stn. $605-1$. Elephant Island, $61^{\circ} 20.35^{\prime} \mathrm{S}$ $55^{\circ} 29.16^{\prime} \mathrm{W}, 146-151 \mathrm{~m}$, Bottom trawl, 19 December 2006. BMNH (1933.3.23.659) one female, holotype, Discovery Expedition, Stn. 170, Off Cape Bowles, Clarence Island, $61^{\circ} 25^{\prime} 30^{\prime} \mathrm{S} 53^{\circ} 46^{\prime} \mathrm{W}, 342 \mathrm{~m}$, R. Large dredge, 1925-31.

\section{Diagnosis}

Proboscis styliform, longer than trunk. Trunk with dorsomedial conical tubercles on segmentation ridges. Ocular tubercle tall, rounded at apex. Anterior cephalic segment with tubercles dorsal to chelifore insertion. Abdomen erect. Chelifores with chelae atrophied. Palps 8-articled, shorter than proboscis, second and fourth articles subequal in length. Legs with setae arranged in longitudinal rows on the longest articles, tibia II is the longest article. Propodi with 2 heel spines of different sizes. Auxiliary claws shorter than half main claw length.

\section{Geographical and bathymetric distribution}

Ammothea longispina shows a wide distribution and depth range. This species should be considered circumpolar with depth range between 57 and 1454 m (Fry and Hedgpeth 1969; Child 1994; Munilla and Soler-Membrives 2009). The specimens here examined were found within the known geographical and bathymetric range for this species.

\section{Remarks}

Gordon (1932) characterized Ammothea longispina by "(1) the long tapering proboscis, (2) the relatively short palp, (3) the very large spine on the propodus and (4) the blunt antero-lateral cephalic lobes". She described another $\mathrm{Am}$ mothea species as "Ammothea sp.?"(this material is described in this paper as A. isabellae n. sp.) because it bears a strong superficial resemblance to the holotype of Ammothea longispina. Both Gordon's species are similar morphologically, but they have different critical characters: A. longispina has an 8-articled palp, a proboscis longer than the trunk and an anterior cephalic segment with 
tubercles; while Ammothea sp.? has a 9-articled palp (after Gordon, 1932: 108), a proboscis shorter than the trunk and has no anterior tubercles on the cephalic segment.

Fry and Hedgpeth (1969) considered that Gordon (1932) "confused by the 9-segmented palp was doubtful of the exact position of her specimen" (Ammothea sp.?) and then considered this latter material as belonging to A. longispina. These authors also examined a juvenile specimen, which had a palp with seven articles. Hence, they considered that the number of palp articles in this species is variable between seven and nine, as did subsequent authors (Pushkin 1993; Child 1994).

Variation in the number of palp articles is difficult to envisage in adults of the same species of Ammothea. The number of palp articles is an important taxonomic character, and its variability should be accepted when several specimens show this condition. The palp of Ammothea longispina should be considered 8-articled because the mention of a 9-articled condition is only based on the observation of a single specimen recorded as Ammothea sp.? by Gordon, 1932. Other taxonomic characters should also be consulted to consider if both forms actually belong to the same species or not (see above in this paper).

Fry and Hedgpeth $(1969$, p. 90) considered that the palp of A. longispina can be formed of seven articles, because the juvenile specimens they examined showed that condition. However, juvenile (ontogenetic) characters should not be considered for diagnosing species, nor in comparison with other adult characters; only adult characters should be considered. As with other pycnogonids, Ammothea species achieve all adult-stage characters in the course of successive moults.

Our specimens agree in general aspects with the descriptions given by Gordon (1932) for the holotype specimen. She pointed out a very large spine on the propodus; the propodus has two heel spines, the proximal one being shorter than the distal (Gordon 1932, fig. 50b). However, in one of our specimens (MZB 2013-3705), the proximal heel spine is the longest one. If this is a teratology, variability or the presence of sibling species should be examined with more abundant material than that currently available for this study.

\section{Ammothea minor (Hodgson, 1907)}

Leionymphon minus Hodgson, 1907, p. 44, pl. VI. Helfer and Schlottke, 1935, p.284.

Ammothea gracilipes. Bouvier, 1913, pp. 132-135, figs. 85-87.

Ammothea minor. Bouvier, 1913, pp. 131-132, figs. 83-84. Calman, 1915, pp. 52-53. Loman, 1923, p. 23. Hodgson, 1927, p. 342 (key). Gordon, 1932, pp. 103--04. 1938, pp. 21-22. 1944, p. 51. Fage, 1952, pp. 271-272. Stock, 1965, p. 2. Clark, 1977, pp. 174-175. Krapp, 1980, p.2.
Pushkin, 1993, pp. 291-293. Child, 1994, p. 25. Munilla and Soler-Membrives, 2009, p. 100 (list.).

Ammothea (Theammoa) minor. Fry and Hedgpeth, 1969, pp. 79-81, figs. 104, 105, 116, 119.

Material examined

BEIM (CRP-85), one larvigerous male, Polarstern cruise XXIII/8, stn. 608-1, Elephant Island, $61^{\circ} 11.340 \mathrm{~S}$ $54^{\circ} 43.170 \mathrm{~W}, 284-293 \mathrm{~m}$, Bottom trawl, 20 December 2006. MZB (2013-1872), one larvigerous male, Polarstern cruise XXIII/8, stn. 614-3, Elephant Island, $60^{\circ} 52.37^{\prime} \mathrm{S}$ $55^{\circ} 29.80^{\prime} \mathrm{W}, 248-259 \mathrm{~m}$, Agassiz trawl, 21 December 2006.

\section{Diagnosis}

Proboscis pyriform. Trunk with conical tubercles at dorsomedian points on segmentation ridges, as tall as or taller than ocular tubercle. Chelifores short, slender with chelae atrophied. Palp 9-articled, 5-8 articles asymmetrically conical or cylindrical. Second tibia the longest article of the legs. Propodus with 4-7 homogeneous short heel spines and confined within half the length of the propodal sole.

Geographical and bathymetric distribution

Fry and Hedgpeth (1969) and Child (1994) summarized all geographical and bathymetric information on this species. According to these authors, this species should be considered circumpolar, with a depthrange between 15 and $392 \mathrm{~m}$. Others authorsaddlittlenew data, modifying the knowndepthrange to 8-392 m (Pushkin 1993; Munilla and Soler-Membrives 2009). Our geographical and bathymetric sampling data are included in the known distribution of this species.

\section{Remarks}

The material examined for this study agrees in general aspects with the descriptions given by Hodgson (1907) and Bouvier (1913) and subsequent ones provided by Calman (1915), Fry and Hedgpeth (1969), Pushkin (1993) and Child (1994); except for the length proportions of the claw and auxiliary claws. In specimens described by these authors, the auxiliary claws are similar to or shorter than half the main claw (e.g. 0.42-0.57 in Fry and Hedgpeth 1969, p.80), while in our specimens, the auxiliary claws are distinctly longer than half the main claw (the auxiliary claw is 0.64 and 0.69 times the main claw length).

Ammothea spinosa (Hodgson, 1907)

Leionymphon spinosum Hodgson, 1907, pp. 49-50, pl. VII.- Bouvier, 1906b, p. 55.- Helfer and Schlottke, 1935, p. 284. 
Ammothea spinosa. Bouvier, 1913, p. 123.- Calman, 1915, p. 52.- Hodgson, 1927, pp. 341-342. Gordon, 1932, p. 103, fig. 53.- Clark, 1977, pp. 174-175.- Child, 1982, pp. 3-4.Pushkin, 1993, pp. 301-302, fig. 272.- Child, 1994, pp. 27-28.- Chimenz Gusso and Gravina, 2001, pp. 338-339.- Munilla and Soler-Membrives, 2009, p. 100.- Weis and Melzer, 2012, p. 190.- Cano and LópezGonzález, 2013, p. 338, figs. 5a and 6a.

Ecleipsothremma spinosa. Fry and Hedgpeth, 1969, pp. 96-97, figs. 126 and 148.- Turpaeva, 1974, p. 285.

\section{Material examined}

MZB (2013-3707), one adult male, Polarstern cruise XXIII/8, stn. 654-1, Elephant Island, $61^{\circ} 22.01^{\prime} \mathrm{S}$ $56^{\circ} 00.95^{\prime} \mathrm{W}, 353-356 \mathrm{~m}$, Bottom trawl, 28 December 2006. MZB (2013-3708), one adult female, Polarstern cruise XXIII/8, stn. 695-1, Bransfield Strait, $63^{\circ} 00.55^{\prime} \mathrm{S}$ 58 38.01'W, 269-293 m, Bottom trawl, 6 January 2007. BEIM (CRP-92), one adult male, Polarstern cruise XXIII/ 8, stn. 653-1, Elephant Island, $61^{\circ} 19.59^{\prime} \mathrm{S} 56^{\circ} 00.24^{\prime} \mathrm{W}$, 344-356 m, Bottom trawl, 28 December 2006.

\section{Diagnosis}

Proboscis shorter than trunk length, cylindrical, slightly swollen in the middle, with flat lip and rounded distal part. Trunk with tall conical tubercles at dorsomedian points on segmentation ridges. Ocular tubercle taller than dorsomedian tubercles, distally pointed. Chelifores nonfunctional, the articulation of the scape and palm is syntaxial. Palp 9-articled. Propodus of the first and second legs markedly different from those of the third and fourth.

Geographical and bathymetric distribution

This species is known from different localities from the Scotia Sea, Antarctic Peninsula, Ross Sea, Weddell Sea and South America, in a wide depth range of 73-1,679 m (Child 1994; Chimenz Gusso and Gravina 2001; Fry and Hedgpeth 1969; Munilla and Soler-Membrives 2009; Pushkin 1993; Weis and Melzer 2012). Our geographical and bathymetric sampling data are included in the known distribution of this species.

\section{Remarks}

Fry and Hedgpeth (1969) and Child (1994) compared this species with Ammothea allopodes, because they were the only two Ammothea species with dimorphism between anterior and posterior propodi. The general shape of dorsomedial tubercles, the orientation of the abdomen or the presence of a basal tubercle have been used as some of the distinguishing characters between the two species. Recently, Cano and López-González (2013) considered a wide variability of these characters, and they propose as discriminating characters the morphology of the proboscis, the relative length of the proximal four articles of the palp and the articulation of the scape and palm of the chelifore. These authors considered these discriminating characters when describing an additional new Ammothea species with dimorphism between anterior and posterior propodi, Ammothea pseudospinosa Cano and López-González 2013.

Descriptions given by Hodgson (1907) and Bouvier (1913), and subsequent ones provided by Fry and Hedgpeth (1969) and Child (1994), characterized A. spinosa by the presence of setae on the dorsomedial tubercles and on the leg surfaces. However, our specimens have short setae which are few in number. This variability is, at this moment, here considered to be intraspecific.

\section{Ammothea striata (Möbius, 1902)}

Leionymphon striatum Möbius, 1902, pp. 183-184, pl. XXVI.- Bouvier, 1906b, p. 55.- Hodgson, 1907, p. 40.Bouvier, 1911b, p. 1140.

Ammothea striata. Bouvier, 1913, pp. 124-126, figs. 7-12.Calman, 1915, p. 55.- Hodgson, 1927, pp. 341-342.- Gordon, 1932, pp. 96-97.- Gordon, 1938, p. 22.- Clark, 1977, pp. 174-175.- Munilla, 1991, pp. 23-24.- Child, 1994, pp. 28-29.- Munilla, 2001, p. 145.- Munilla and SolerMembrives, 2009, p. 100.

Tavmastopycnon striata. Fry and Hedgpeth, 1969, pp. 91-92, figs. 139-142.- Pushkin, 1993, pp. 319-320, figs. 293-294.

\section{Material examined}

BEIM (CRP-93), three adult females, Polarstern cruise XXIII/8, stn. 605-3, Elephant Island, $61^{\circ} 20.33^{\prime} \mathrm{S}$ $55^{\circ} 31.53^{\prime} \mathrm{W}, 137-154 \mathrm{~m}$, Agassiz trawl, 20 December 2006. MZB (2013-3709), one adult male, Polarstern cruise XXIII/8, stn. 664-1, South Shetland Islands, 61³8.86'S 57 $48.04^{\prime} \mathrm{W}, 337-336$ m, Bottom trawl, 30 December 2006.

\section{Diagnosis}

Proboscis curved ventrally, tapering at the end. Trunk with low rounded tubercles at dorsomedian points on segmentation ridges. Ocular tubercle conical as tall as or taller than dorsomedian tubercles. Chelifores with chelae fully formed. Palp 9-articled, second and fourth articles similar in length. Legs with rows of short spines on the long articles. Propodi without heel spines. Auxiliary claws about half main claw length. 
Geographical and bathymetric distribution

Fry and Hedgpeth (1969), Pushkin (1993) and Child (1994) summarized all geographical and bathymetric information on this species. According to these authors, this species should be considered circumpolar, with a depth range between 75 and $567 \mathrm{~m}$. Data recorded by other authors (Munilla 2001; Munilla and Soler-Membrives 2009), and our geographical and bathymetric sampling data are included in the known distribution of this species.

\section{Remarks}

The material examined for this study agrees in general aspects with the descriptions given by Möbius (1902) and subsequent ones by Bouvier (1913), Fry and Hedgpeth (1969), Munilla (1991), Pushkin (1993) and Child (1994). Child (1994) briefly diagnosed a set of characters for this species, pointing out that auxiliary claws can reach more than half the main claw length. In our specimen as well as in those previously described, the auxiliary claws are about half the main claw length.

Ammothea tibialis Munilla, 2002

Ammothea tibialis Munilla, 2002, pp. 171-173, fig. 1.Munilla and Soler-Membrives, 2009, p. 100 (list.).

\section{Material examined}

MZB (2013-3710), one adult female, Polarstern cruise XXIII/ 8 , stn. 654-1, Elephant Island, $61^{\circ} 22.01^{\prime} \mathrm{S} 56^{\circ} 00.95^{\prime} \mathrm{W}$, 353-356 m, Bottom trawl, 28 December 2006.

\section{Diagnosis}

Proboscis cylindrical, straight, and shorter than trunk in length. Trunk with conical-rounded dorsomedian tubercles on posterior ridges of each segment, lateral processes with a pair of dorsodistal pilose tubercles and narrowly separated (except last pair). Ocular tubercle as tall as the first dorsomedian tubercle, cylindrical, swollen around eyes and with low apical cone. Cephalic segment with two low anterior tubercles. Chelifores with atrophied chelae. Palp 9-articled, second article is the longest. Legs with femur as the longest article. Tibiae with ten rows of spines (four dorsal, four ventral and two lateral ones) and femur only has six rows (two dorsal, two ventral and two lateral ones). Propodus with three heel spines. Auxiliary claws shorter than half main claw length.

Geographical and bathymetric distribution

This species has only been reported in the original description by Munilla (2002) (one male, holotype). Type locality is Scotia Sea (Drake Passage) at $710 \mathrm{~m}$ depth. Our specimen was collected off Elephant Island (Scotia Sea), between 353 and $356 \mathrm{~m}$ depth. Two specimens are now known.

\section{Remarks}

The material examined for this study agrees in general aspects with the descriptions given by Munilla (2002), although there are some differences between the original description and the specimen here examined: Munilla (2002) pointed out a proboscis without constriction and with the same diameter throughout, but our specimen shows a proboscis with a slight reduced diameter on the proximal half; hototype has propodi with three heel spines, the most proximal spine markedly smaller and the female here examined has propodi with three heel spines increasing in size from the proximal to the distal one; finally, the proportions between the auxiliary and main claw lengths are also slightly different. In Munilla's specimen, the auxiliary claws are 0.35 of the main claw length, while in our specimen, the auxiliary claws are 0.45 .

\section{Key to Southern Ocean species of Ammothea (Adults)}

Child (1994) proposed the latest key to the species of Ammothea from the Southern Oceans, more than 15 years after the previous ones prepared by Fry and Hedgpeth (1969) and Clark (1977). During that period, new species were described, and new materials were collected, increasing our knowledge of the variability of some characters, making it necessary to update Fry and Hedgpeth's and Clark's keys. Child (1994) included in his key the 17 known Antarctic and sub-Antarctic species of Ammothea. For similar reasons, it is now necessary to update Child's key, because 30 species of this genus are now known. Although an improvement on previous proposals, Child's key included terms which are sometimes difficult to express precisely (e.g. slightly, moderate, slender), and some contradictory sentences, making it sometimes difficult to achieve correct, unambiguous identifications.

Munilla and Soler-Membrives (2009) cited 26 Ammothea species for Antarctic and sub-Antarctic waters, but some of them are different to the ones considered for this key. Munilla and Soler-Membrives (2009) considered: 1) Ammothea bicorniculata as a synonym of A. allopodes, but as commented on above, both species have different critical characters (see the remarks on A. bicorniculata in this paper); 2) Ammothea cooki (Child, 1987) and Ammothea dubia (Hedgpeth, 1950) as valid species. However, the first one is currently accepted in the genus Ascorrynchus, while 
the second one is considered a Nomen dubium in the genus Boehmia, and it has not been demonstrated that it should belong to the genus Ammothea, or even if it should be considered at all as its description was based on a juvenile form; and 3) Ammothea gibbosa Bouvier, 1913 as a valid species. However, Colossendeis gibbosa Möbius, 1902 (not Bouvier, 1913) is accepted as a synonym of Ammothea carolinensis.

In consideration that a key to a species should be a practical tool, in the present contribution, we propose a dichotomous key to the species of the genus Ammothea from Antarctic and sub-Antarctic waters and have attempted to avoid subjective expressions and include precise characters or ranges of variation with discriminant value.

Key to Antarctic and sub-Antarctic species of Ammothea (adults)

\begin{tabular}{|c|c|c|}
\hline \multirow[t]{2}{*}{1.} & $\begin{array}{l}\text { Adults with chelifores bearing } \\
\text { chelae with developed fingers } \\
\text { (functional) }\end{array}$ & 2 \\
\hline & $\begin{array}{l}\text { Adults with chelifores with } \\
\text { atrophied finger or severely } \\
\text { reduced finger (non-functional) }\end{array}$ & 8 \\
\hline \multirow[t]{2}{*}{2 . } & With heel spines & 3 \\
\hline & Without heel spines & 6 \\
\hline \multirow[t]{2}{*}{3.} & $\begin{array}{l}\text { Length fourth palp article/length } \\
\text { second article } 0.8-1.4 \text {. Auxiliary } \\
\text { claw equal or less than half main } \\
\text { claw length }\end{array}$ & 4 \\
\hline & $\begin{array}{l}\text { Length fourth palp article/length } \\
\text { second article } 1.9-2.5 \text {. Auxiliary } \\
\text { claw more than half main claw } \\
\text { length }\end{array}$ & $\begin{array}{l}\text { A. hesperidensis Munilla, } \\
2000\end{array}$ \\
\hline \multirow[t]{2}{*}{4.} & Trunk longer than proboscis & 5 \\
\hline & Trunk shorter than proboscis & $\begin{array}{l}\text { A. childi Cano and } \\
\text { López-Gónzalez, } 2012\end{array}$ \\
\hline \multirow[t]{2}{*}{5.} & $\begin{array}{l}\text { Proboscis more than twice as long } \\
\text { as wide. Ratio trunk/proboscis } \\
\text { length }<1.5 \text {. Ratio length/width } \\
\text { of cheliphore scape about } 4\end{array}$ & A. gigantea Gordon, 1932 \\
\hline & $\begin{array}{l}\text { Proboscis less than twice as long } \\
\text { as wide Ratio trunk/proboscis } \\
\text { length about } 3 \text {. Ratio length/ } \\
\text { width of cheliphore scape }<3\end{array}$ & $\begin{array}{l}\text { A. bicorniculata Stiboy- } \\
\text { Risch, } 1992\end{array}$ \\
\hline \multirow[t]{2}{*}{6.} & $\begin{array}{l}\text { Two spinose humps on each dorsal } \\
\text { ridge of trunk. Dorsomedian } \\
\text { cylindrical structure at second } \\
\text { coxa and with dorsodistal } \\
\text { tubercles on second and third } \\
\text { coxa. }\end{array}$ & $\begin{array}{l}\text { A. bigibbosa Munilla and } \\
\text { Ramos, } 2005\end{array}$ \\
\hline & $\begin{array}{l}\text { A single hump on each dorsal } \\
\text { ridge of trunk. Without } \\
\text { dorsomedian or dorsodistal } \\
\text { structures on coxae }\end{array}$ & 7 \\
\hline
\end{tabular}

continued

7. Proboscis slender, tapering distally (banana-shaped), curved ventrally to about $90^{\circ}$, without any inflated area along. Chela subequal or longer than scapus in length.

Proboscis proximally inflated, distally a slender moderately downcurved cylinder. Chela shorter than scapus in length.

8. Palps shorter than proboscis.

Palps longer than proboscis

9. Proboscis styliform

Proboscis not styliform

10. Palp 8-articled, anterior cephalic segment with tubercles

Palp 9-articled, anterior cephalic segment without tubercles

11. Palp 8-articled

Palp 9-articled

A. adunca Child, 1994

9

11

10

A. sextarticulata Munilla, 1989

A. longispina Gordon, 1932

A. isabellae n. sp.

A. tetrapora Gordon, 1932

12

12. Transverse body ridges low without medial tubercles

Transverse body ridges prominent, 14 with medial tubercles

13. Two groups of sole spines, proximal group (heel spines) subequal in length. Ratio fourth/ second palp article length $\geq 1$

Two groups of sole spines, proximal group (heel spines) with the most proximal spine distinctly smaller. Ratio fourth/ second palp article length $<1$

14. Propodus similar for all four legs

Propodus of first and second distinctly different from those of the third and fourth legs

15. Dorsomedial tubercle on two trunk segments

Dorsomedial tubercle on three trunk segments

16. Length second palp article/length fourth article $\geq 1.4$

Length second palp article/length fourth article $<1.4$

17. Proboscis similar length to trunk, moderately slender, distally inflated from proximal cylinder. Abdomen without basal tubercle

Proboscis shorter than trunk, cylindrical, rounded without constriction. Abdomen with a small spinose basal tubercle

\section{A. magniceps Thomson,} 1884

A. clausi Pfeffer, 1889

15

27

29

16

18

A. meridionalis Hodgson, 1915

A. tibialis Munilla, 2002 
continued

18. Proboscis styliform (gradually narrowing distally)

Proboscis not styliform

$>1.5$

Length trunk/length proboscis $<1.4$

20. Length scape/length proboscis $>0.5$

Length scape/length proboscis $\leq 0.5$

21. With well-developed spines on the distal dorsal surface of the lateral processes

Without or very minute spines on the distal dorsal surface of the lateral processes

22. Proboscis massive, about twice as long as wide. Fourth palp article with external glandular pore

Proboscis more elongate, from 2.5 to about 4 times as long as wide. Fourth palp article without external glandular pore

23. Propodus with spines on the distal half of the sole

Propodus without spines on the distal half of the sole

24. Propodus with 4-7 spines (homogeneous in size) within proximal half sole. Ratio fourth/ second palp article length $<1.3$

Propodus with 3 heel spines (distinctly heterogeneous in size). Ratio fourth/second palp article length $>1.5$

25. Proboscis cylindrical, inflated at proximal half portion, more or less cylindrical on distal half. Ratio proboscis/scapus length $<3$

Proboscis narrow proximally, but swollen along the $2 / 3$ distal portion. Ratio proboscis/scapus length $>3$

26. Trunk with conspicuous (tall) conical tubercles at dorsomedial points on segmentation ridges. Propodus with a group of 8-9 spines (not completely homogeneous in size) along the entire sole

Trunk without conspicuous conical tubercles at dorsomedial points on segmentation ridges. Propodus with 4 long spines on distal part of the sole (none of them are heel spines).

\section{A. minor (Hodgson,} 1907)

\section{A. victoriae Cano and}

López-González, 2007 A. carolinensis Leach,
1814

\section{A. bentartica Munilla, 2001}

A. gordonae Child, 1994 stylirostris Gordon, 1932

19

20

continued

27. First four palp articles much longer than the proboscis length. The ocular tubercle is distally rounded. Proboscis egg shaped

First four palp articles subequal or 28 shorter than proboscis length. The ocular tubercle is distally pointed. Proboscis more or less cylindrical

A. calmani Gordon, 1932

A. armentis Child, 1994

A. australiensis Flynn, 1919

22

A. glacialis (Hodgson, 1907)

28. Proboscis cylindrical, slightly swollen in the middle, with rounded distal part. Lateral processes with paired dorsodistal curved pointed tubercles

Proboscis more or less cylindrical, with a two-thirds proximal part slightly inflated, after it a distinct constriction, and a wider and angular trilobulated distal part. Lateral processes without paired dorsodistal curved pointed tubercles

29. Dorsomedial tubercles of similar heights

\section{A. antipodensis Clark} 1971

Dorsomedial tubercles markedly taller on segment 2 than on segment 3

\author{
A. spinosa (Hodgson, \\ 1907)

\section{A. pseudospinosa Cano and López-González, 2013}

A. uru Clark, 1977
Acknowledgments The authors would like to express their gratitude to Miranda Lowe (British Museum of Natural History) for the location of the type material of Ammothea longispina and Ammothea $s p . ?$ in the collections of the BMNH. Our thanks are also addressed to the officers and crew and many colleagues for their help on board during the Polarstern ANT XXIII/8 cruises. We take this opportunity to extend our thanks to the cruise leader and steering committee of the cruise, especially Julian Gutt and Enrique Isla (ANT XIII/8), all of whom kindly facilitated the work on board and allowed us to collaborate in this Antarctic programme. Support for this work was provided by POL2006-06399/CGL (Polarstern ANT XXIII/8 - CLIMANT). Mr. Tony Krupa is thanked for reviewing the English version.

\section{References}

Arnaud PM, Jazdzewski K, Presler P, Sicinski J (1986) Preliminary survey of benthic invertebrates collected by Polish Antarctic expeditions in Admiralty Bay (King George Island, South Shetland Islands, Antarctica). Pol Polar Res 7:7-24

Arntz WE, Brey T, Gallardo VA (1994) Antarctic zoobenthos. Oceanogr Mar Biol, Ann Rev 32:241-304

Bamber RN (2011) The sea-spiders (Arthropoda: Pycnogonida) of Admiralty Bay, King George Island. Pol Polar Res 32:27-38

Bouvier EL (1905) Observations preliminaries sur les Pycnogonides recueillis dans la région antarctique par la misión du Français. Bull Mus Natl Hist Nat, París 11:294-298

Bouvier EL (1906a) Nouvelles observations sur les Pycnogonides recueillis dans les régions antarctiques au tours de la campagne 
dirigée par M. Jean Charcot. Compt Rend Hebd Seances Acad Sci, París 142:15-22

Bouvier EL (1906b) Pycnogonides du Français. Exped Antarct Franç 1903-1905:1-69

Bouvier EL (1911) Les Pycnogonides des Pourquoi Pas? Compt Rend Hebd Seances Acad Sci 152:1136-1142

Bouvier EL (1913) Pycnogonides du pourquoi Pas?. Deux Expéd Antarct Française (1908-1910) 6:1-169

Calman WT (1915) Pycnogonida. British Antarctic (Terra Nova) Expedition, 1910. Nat Hist Zool 3:1-74

Calman WT (1920) On a collection of Pycnogonida from the South Orkney Islands. Ann Mag Nat Hist Ser 9:244-247

Cano E, López-González PJ (2007) Ammotheidae (Arthropoda: Pycnogonidae) collected during the Victoria Land transect cruise 2004 (Ross Sea, Antarctica), with a description of a new species of Ammothea. Mar Biol Res 3:438-445

Cano E, López-González PJ (2013) Two new species of Ammothea (Pycnogonida, Ammotheidae) from Antarctic waters. Helgol Mar Res 67:337-347

Child CA (1982) Deep-sea Pycnogonida from the North and South Atlantic Basins. Smithson Contrib Zool 349:1-54

Child CA (1994) Antarctic and Subantarctic Pycnogonida 1. The Family Ammotheidae. Antarct Res Ser 63:1-48

Chimenz Gusso C, Gravina MF (2001) Faunistic and biological traits of some Antarctic Pycnogonida. Ital J Zool 68:335-344

Clark WC (1977) The Genus Ammothea Leach (Pycnogonida) in New Zealand Waters: New species and a review. J R Soc N Z Zool 7:171-187

Fage L (1952) Pycnogonides de la Terre Adélie. Bull Mus Natl Hist, París 24:263-273

Fry WG, Hedgpeth JW (1969) Pycnogonida, 1. Colossendeidae, Pycnogonidae, Endeidae, Ammotheidae. Fauna of the Ross Sea 7. N Z Oceanogr Inst Mem 49:1-139

Gordon I (1932) Pycnogonida. Disccov Rep 6:1-138

Gordon I (1938) Pycnogonida. Sci Rep Australas Antarct Exped $2: 1-40$

Gordon I (1944) Pycnogonida. Rep B A N Z Antarct Res Exped 5:1-172

Hedgpeth JW (1950) Pycnogonida of the United States Navy Expedition, 1947-48. Proc U S Natn Mus 100:147-160

Helfer H, Schlottke E (1935) Pantopoda. Dr. H. G. Bronns Kl Ordn Tierreichs 5:1-314

Hodgson TV (1907) Pycnogonida. National Antarctic Expedition 1901-1904. Reports of the National Antarctic expedition of 1901-1904. Nat Hist 3:1-172

Hodgson TV (1908) The Pycnogonida of the Scottish National Antarctic expedition. Trans R Soc Edinb 46:159-188

Hodgson TV (1927) Die Pycnogoniden der Deutschen SüdpolarExpedition 1901-1903. Dtsch Südpolar Exped Ser II Zool 19:303-358

Krapp F (1980) Neue Pantopodenfunde (Pycnogonida, Arthropoda) nahe der Belgischen Antarktis-Station. Bulletin del'Institut Royal des Sciences Naturelles Belgique 52:1-8

Leach WE (1814) The zoology miscellany. London 1:1-144
Loman JCC (1923) The Pycnogonida. Furth Zool Results Swed Antarct Exped 1:1-41

Möbius K (1902) Die Pantopoden der Deustschen Tiefsee-Expedition, 1898-99. Wiss Ergebn Dt Tiefsee Exped "Valdicia” 1898-1899 3:177-196

Müller HG (1993) World catalogue and bibliography of the recent Pycnogonida. Laboratory for Tropical Ecosystems, Wetzlar

Munilla T (1991) Picnogónidos capturados en la campaña "antártica 8811”. Bol Inst Esp Oceanogr 7:3-44

Munilla T (2000) A new species of Ammothea and other pycnogonids from around Livington Island, South Shetland Islands, Antarctica. Antarct Sci 12:47-51

Munilla T (2001) Synopsis of the pycnogonids from Antarctic and Subantarctic waters. Polar Biol 24:941-945

Munilla T (2002) Ammothea tibialis, a new pycnogonid from Drake Pasaje, Antarctica. Antarct Sci 14:171-173

Munilla T (2005) Ammothea bigibbosa (Arthropoda, Pycnogonida), a new species of the Antarctic Peninsula waters. Polar Biol 29:70-72

Munilla T, Soler-Membrives A (2007) The occurrence of pycnogonids associated with the volcanic structures of Bransfied Strait central basin (Antarctica). Sci Mar 71:699-704

Munilla T, Soler-Membrives A (2009) Check-list of the pycnogonids from Antarctic and sub-Antarctic waters: zoogeographic implications. Antarct Sci 21:99-111

Nielsen JF, Lavery S, Lörz AN (2009) Synopsis of a new collection of sea spiders (Arthropoda: Pycnogonida) from the Ross Sea, Antarctica. Polar Biol 32:1147-1155

Pfeffer G (1889) Zur Fauna von Süd-Georgien. Jahrb Hamb Wiss Anst 6:39-55

Pushkin AF (1993) The pycnogonida fauna of the South Ocean. Biological results of the soviet Antarctic expeditions. Russian Academy of Sciences. Explor Fauna Seas 20:1-397

Soler-Membrives A, Turpaeva E, Munilla T (2009) Pycnogonids of the Eastern Weddell Sea (Antarctica), with remarks on their bathymetric distribution. Polar Biol 32:1389-1397

Stiboy-Risch C (1992) Ammothea bicorniculata, eine neue art der Ammotheidae aus der Antarktis (Pantopoda, Pycnogonida). Bonn Zool Beitr 43:333-338

Stock JH (1965) Pycnogonides provenant de la base Antarctique Belge. Bull Inst R Sci Nat Belg 41:1-2

Turpaeva EP (1974) The pycnogonids of the Scotia Sea and surrounding waters. Trudy Instituta Okeanologii P.P. Shirshow, Akad Nauk SSSR 98:277-305

Turpaeva EP (1998) Annoted list of pantopods (Pycnogonida) from Eastern part of Weddell Sea. Benthos of the high latitude regions. VNIRO Publishing House, Moscow, pp 56-68

Weis A, Melzer RR (2012) Chilean and Subantarctic Pycnogonida collected by the "Huinay fjordos" expeditions 2005-2011. Zoosyst Evol 88:185-203

Weis A, Friedrich S, Melzer RR (2011) Antarctic Pycnogonida housed at the Bavarian State collection of zoology. Zoosyst Evol 87:297-317 